\title{
Habitat tracking, range dynamics and palaeoclimatic significance of Eurasian giant salamanders (Cryptobranchidae) - indications for elevated Central Asian humidity during Cenozoic global warm periods
}

\author{
Madelaine Böhme ${ }^{\mathrm{a}, \mathrm{b}, *}$, Davit Vasilyan $^{\mathrm{b}}$, Michael Winklhofer ${ }^{\mathrm{c}}$ \\ a Senckenberg Center for Human Evolution and Palaeoecology (HEP), Germany \\ b Eberhard-Karls-University Tuebingen, Department for Geoscience, Sigwartstr. 10, 72076 Tuebingen, Germany \\ ' Department of Earth- and Environmental Science, Ludwig-Maximillians-University Munich, Theresienstr. 41, 80333 Munich, Germany
}

\section{A R T I C L E I N F O}

\section{Article history}

Received 17 December 2010

Received in revised form 23 April 2012

Accepted 26 April 2012

Available online 4 May 2012

\section{Keywords:}

Giant salamanders

Environmental stasis

Palaeoprecipitation

Central Asia

Global warm periods

\begin{abstract}
A B S T R A C T
Environmental fluctuations are a driving force in vertebrate evolution, but cryptobranchids (giant salamanders) show little morphologic change since the Jurassic. Here we analyze their fossil distribution in the Cenozoic of Eurasia and show that morphologic stasis is also maintained by stable environments, making giant salamanders an ideal proxy-group for environmental and palaeoclimatic studies. The climate space of recent and fossil cryptobranchids is best characterized by high humidity with mean annual precipitation values over $900 \mathrm{~mm}$. The recorded patchiness of their fossil record can be explained by habitat tracking and/or range expansion from higher altitudes into lowland settings during humid periods with increased basinal relief. In Central Asia cryptobranchids are recorded from five intervals, four of them are global warm periods: Paleocene-Eocene Thermal Maximum, Late Oligocene warming, Miocene Climate Optimum, and Mio-Pliocene transition. This distribution suggests that during global warmth the Asian cold high pressure zone during winter months may be weak or absent, thus moist westerly winds penetrate far into the continent. The presence of cryptobranchids also indicates that the aridification across the EoceneOligocene boundary as reported from Mongolia and northwestern China, does not occur in the Zaysan Basin, probably due to increased upslope precipitation in the rising Altai Mountains.
\end{abstract}

(c) 2012 Elsevier B.V. All rights reserved.

\section{Introduction}

Cryptobranchids represent a group of large sized (up to $1.8 \mathrm{~m}$ ), paedomorphic basal salamanders known since the Middle Jurassic (Gao and Shubin, 2003; Frost et al., 2006). The group has experienced so little morphological change over the last $160 \mathrm{Myr}$ (Gao and Shubin, 2003) that the two extant genera, the North-American Cryptobranchus and the East-Asian Andrias, can be regarded as living fossils. This observed morphologic stasis may be attributed to their high degree of behavioral, physiological, and developmental plasticity (Wake et al., 1982; Gao and Shubin, 2003). Here we analyze the fossil cryptobranchid distribution in Eurasia during the last 60 myrs and suggest that morphologic stasis in giant salamanders may also be maintained by relatively stable longterm environmental conditions, which reduce the adaptive plasticity in populations (Masel et al., 2007). We argue that cryptobranchid

\footnotetext{
* Corresponding author at: Eberhard-Karls-University Tuebingen, Department for Geoscience, Sigwartstr. 10, 72076 Tuebingen, Germany. Tel.: +49 8921805544; fax: +498921806602 .

E-mail addresses: m.boehme@ifg.uni-tuebingen.de (M. Böhme), davit.vasilyan@ifg.uni-tuebingen.de (D. Vasilyan), michael@geophysik.uni-muenchen.de (M. Winklhofer).
}

populations maintained stable environments by habitat tracking or habitat restriction to mountainous refuges during unfavorable conditions in lowland basins. By these, giant salamander fossils can be regarded as very useful palaeoclimatic and palaeoenvironmental proxy organisms.

\section{Eurasian cryptobranchids during the Cenozoic}

Two extant species of cryptobranchids can be found in eastern Eurasia: Andrias davidianus (China) (Fig. 1) and A. japonicus (Japan) (Fig. 2). Both are strictly aquatic amphibians and confined to clear, well-oxygenated, cold mountain streams and rivers. They might occur also in lowland rivers earlier in the Holocene (Thenius, 1954), where they are absent now probably due to increased human hunting pressure.

Cenozoic giant salamanders are known from the mid-latitudes of Eurasia with four genera and five or six species from 53 localities, ranging from the Late Paleocene to the Pleistocene (Table 1, Fig. 3). Besides Aviturus exsecratus and Ulanurus fractus from the latest Paleocene of Mongolia (S-Mongolia, $43^{\circ} \mathrm{N}, 100^{\circ} \mathrm{E}$ ), the Late Eocene species Zaissanurus beliajevae is restricted to the Central Asian Zaysan Basin (SE-Kazakhstan, $50^{\circ} \mathrm{N}, 85^{\circ} \mathrm{E}$ ), whereas the Late Oligocene to Early Pliocene species Andrias scheuchzeri is widely distributed from 


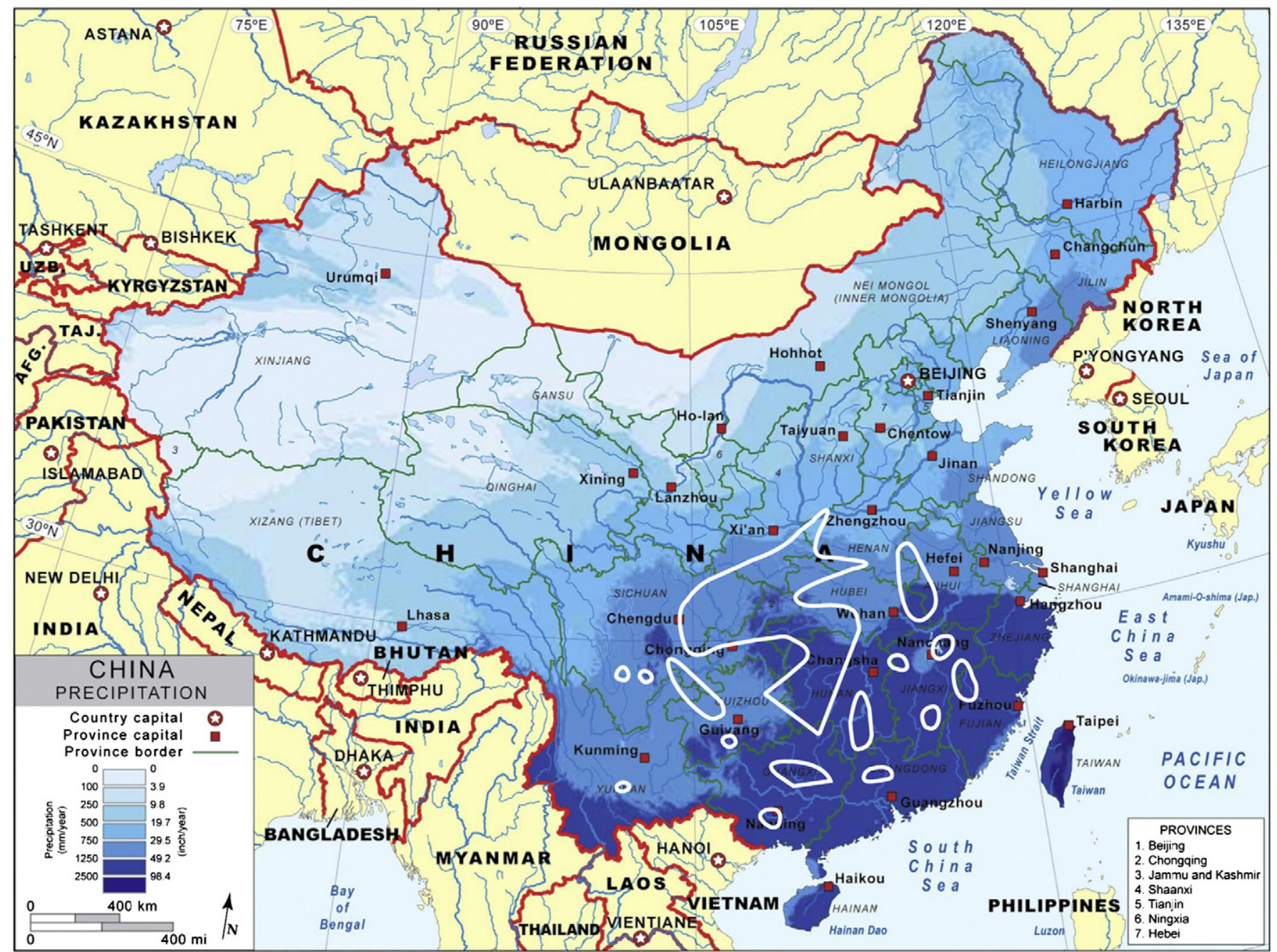

Fig. 1. Current distribution (white lines) of recent Andrias davidianus and mean annual precipitation map of China.

Central Europe to Western Siberia and the Zaysan Basin. The fossil record from their present-day distribution area in East Asia starts late (Early Pliocene) and is so far restricted to Japan (Table 1, Fig. 3).

\subsection{Palaeoclimatic significance of cryptobranchids}

To assess the palaeoclimatic significance of giant salamanders we analyzed climate parameters in their present-day distribution area in East Asia and North America (Table 2) and at selected fossil localities from Europe and Central Asia with an independent palaeoclimate record (Table 3). Humidity turns out to be the key parameter in defining the climate space for cryptobranchids, whereas temperature has a lesser role. All recent and all investigated extinct cryptobranchid species exclusively occur in humid areas, without a distinct dry season and with mean annual precipitation (MAP) exceeding $900 \mathrm{~mm}(900-1.900 \mathrm{~mm})$, irrespective of the related climatic zone, which ranges from warm subtropical to temperate (Tables 2 and 3 ). This strongly suggests that fossil cryprobranchids are a useful proxy for significantly elevated levels (MAP>900 mm) of past humidity. We denote this concordance of ancient and extant humidity requirement as environmental stability, which is remarkable, because recent investigation shows that unlike cryptobranchid salamanders other ectothermic vertebrates display a broad environmental plasticity during their evolution (e.g., the anguin lizard Pseudopus, Klembara et al., 2010).

\subsection{Explaining the fossil cryptobranchid distribution in Eurasia}

In all regions over Eurasia, the fossil distribution is stratigraphically patchy (Fig. 4). In Central Asia cryptobranchids occurred only during five periods; the latest Paleocene, the Late Eocene to earliest Oligocene, the latest Oligocene, the late Early to early Middle Miocene and the Miocene-Pliocene transition (grey bars in Fig. 4). All fossils are found in lowland habitats, within deposits of distal meandric rivers as well as in lake sediments. The occurrence in basinal lacustrine deposits stands in contrast to their recent habitats (Thenius, 1954; Westphal, 1958). However, juvenile individuals have thus far been found only in fluvial sediments, which suggest a habitat shift in ontogeny. To explore their patchiness in stratigraphic distribution, as well as their past habitat extension into lakes in distal basinal settings, the temporal evolution of the palaeoclimate and basin topography can provide keyinformation.

The Neogene humidity evolution in Central Europe is highly variable (as it was probably also in Central Asia), with frequent changes between humid and semi-arid climates (Böhme et al., 2008, 2011). However, cryptobranchids are not recorded in each and every humid period. The patchiness of their fossil record suggests that elevated humidity is a necessary, but not sufficient condition to explain their past distribution. To understand the dependency relationship between this full-aquatic salamanders and humidity we analyze the hypothesis that relatively cool, oxygenated rivers and rivulets, which are a prerequisite for cryptobranchid larval development and typically occur in mountainous 


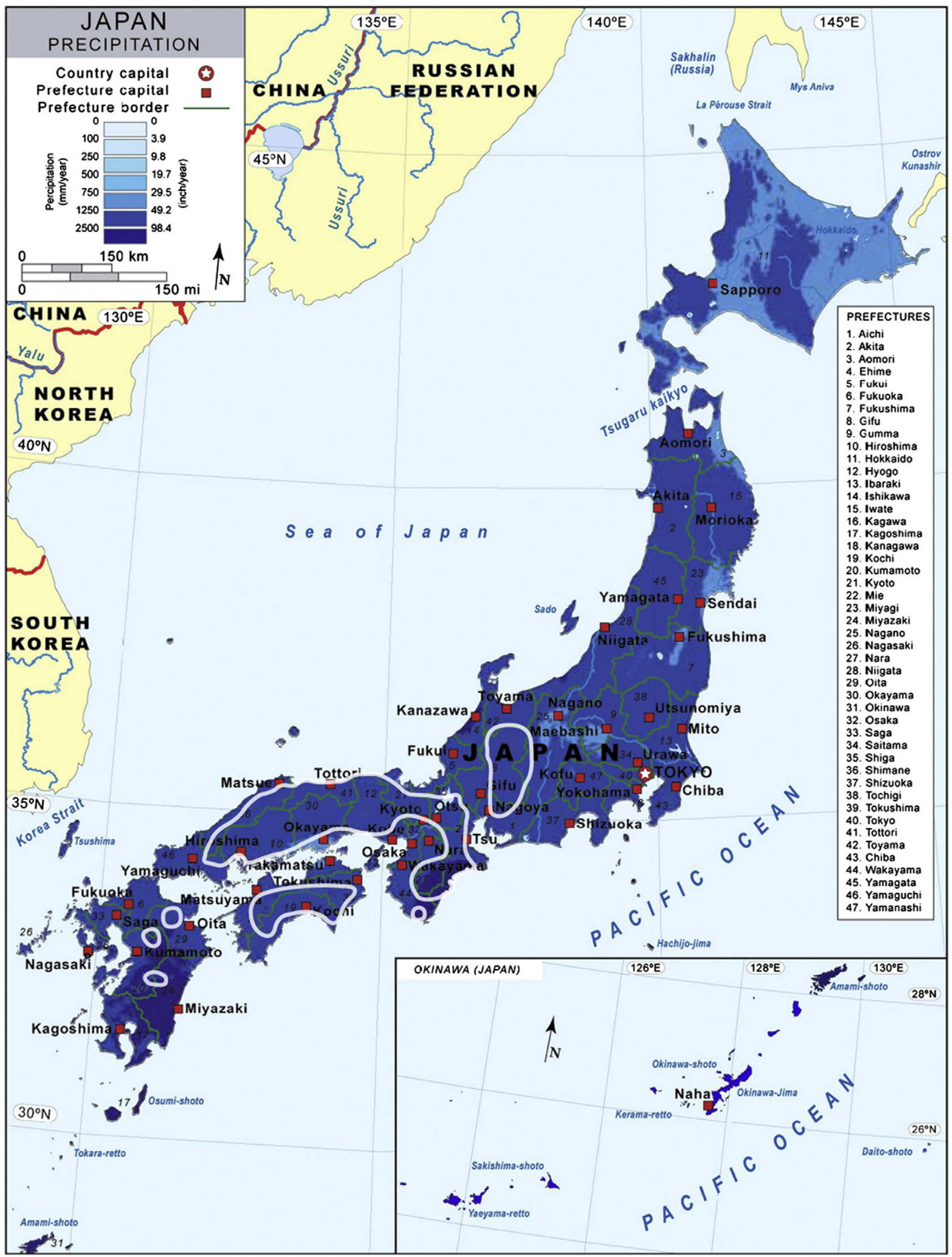

Fig. 2. Current distribution (white lines) of recent Andrias japonicus and mean annual precipitation map of Japan. 
Table 1

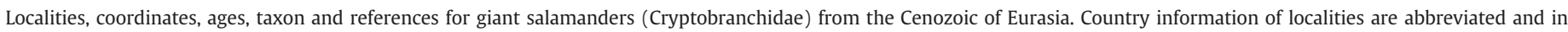
brackets: Au - Austria, Cz - Czechia, Ge - Germany, Gr - Greece, Jp - Japan, Ka - Kazakhstan, Mo - Mongolia, Ru - Russia, Uk - Ukraine.

\begin{tabular}{|c|c|c|c|c|c|c|}
\hline & Locality & Coordinates & Stage & Age (Ma) & Taxon & Reference \\
\hline 1 & Shikimizu quarry (Jp) & N 33.4667 E 132.717 & Late Pleistocene & $0.012-0.126$ & Andrias japonicus & Shikama and Hesegawa, 1962 \\
\hline 2 & Ajimu-Chro (Jp) & N 33.4362 E 131.37 & Piacencian & $2.80-4.30$ & Andrias sp. & Matsui et al., 2001 \\
\hline 3 & Willershausen (Ge) & N 51.7833 E 10.10 & Zanclean & $3.60-5.30$ & Andrias scheuchzeri & Westphal, 1967 \\
\hline 4 & Kuchurgan (Uk) & N 46.75 E 29.9833 & Zanclean & $4.85-5.25$ & Andrias sp. & Chkhikvadze, 1982 \\
\hline 5 & Antipovka (Ru) & N 50.7019 E 40.0167 & Zanclean & $4.896-4.997$ & Cryptobranchidae indet. & Averianov, 2001 \\
\hline 6 & Maramena (Gr) & N 41.1791 E 23.4711 & Zanclean & $5.25-5.50$ & Cryptobranchidae indet. & this paper \\
\hline 7 & Pavlodar 2A (Ka) & N 52.2759 E 79.9897 & Messinian & $5.30-5.60$ & Cryptobranchidae indet. & Chkhikvadze, 1984 , this paper \\
\hline 8 & Götzendorf (Au) & N 48.0167 E 16.5833 & Tortonian & $9.78-9.94$ & Andrias scheuchzeri & Miklas, 2002 \\
\hline 9 & Vösendorf-Brunn ( $\mathrm{Au})$ & N 48.20 E 16.36 & Tortonian & $10.25-10.45$ & Andrias scheuchzeri & Westphal, 1958 \\
\hline 10 & Hammerschmiede 1 (Ge) & N 47.9258 E 10.5989 & Tortonian & $11.08-11.28$ & Andrias sp. & this paper \\
\hline 11 & Gritsev (Uk) & N 49.975 E 27.16 & Tortonian & $11.10-11.50$ & $\begin{array}{l}\text { Andrias scheuchzeri, } \\
\text { Cryptobranchidae gen. et sp. nov. }\end{array}$ & this paper \\
\hline 12 & Mörgen (Ge) & N 48.1521 E 10.5059 & Tortonian & $11.10-13.30$ & Andrias scheuchzeri & Böhme, 2003 \\
\hline 13 & Tiefenried $(\mathrm{Ge})$ & N 48.20 E 10.4833 & Tortonian & $11.10-13.30$ & Andrias scheuchzeri & this paper \\
\hline 14 & Derndorf $(\mathrm{Ge})$ & N 48.183 E 10.4717 & Tortonian & $11.20-12.50$ & Andrias scheuchzeri & Böhme, 2003 \\
\hline 15 & Eppishausen (Ge) & N 48.1669 E 10.5211 & Tortonian & $11.20-12.50$ & Andrias scheuchzeri & Böhme, 2003 \\
\hline 16 & Mataschen $(\mathrm{Au})$ & N 46.903 E 15.9555 & Tortonian & $11.30-11.45$ & Andrias scheuchzeri & Tempfer, 2004 \\
\hline 17 & Wartenberg near Erding (Ge) & N 48.4013 E 11.9993 & Serravallian & $12.00-13.00$ & Andrias sp. & Westphal, 1970 \\
\hline 18 & Zeilarn $(\mathrm{Ge})$ & N 48.2834 E 12.8942 & Serravallian & $12.50-12.70$ & Andrias scheuchzeri & this paper \\
\hline 19 & Oehningen oberer Bruch (Ge) & N 47.6667 E 8.90 & Serravallian & $12.50-13.20$ & Andrias scheuchzeri & Westphal, 1958 \\
\hline 20 & Kirchheim in Schwaben (Ge) & N 48.1833 E 10.4833 & Serravallian & $13.00-14.00$ & Andrias scheuchzeri & Böttcher, 1987 \\
\hline 21 & Poltinik (Ka) & N 47.45 E 84.47 & Langhian & $13.00-15.00$ & Andrias karelcapeki & Chkhikvadze, 1982 \\
\hline 22 & Hambach $6 \mathrm{C}(\mathrm{Ge})$ & N 50.90 E 6.45 & Langhian & $14.50-14.90$ & Andrias scheuchzeri & Böhme, 2003 \\
\hline 23 & Tri Bogatirya (Ka) & N 47.60 E 83.80 & Langhian & $15.00-18.00$ & Andrias karelcapeki & Chkhikvadze, 1982 \\
\hline 24 & Vympel (Ka) & N 47.45 E 84.47 & Langhian & $15.00-18.00$ & Andrias karelcapeki & Chkhikvadze, 1982 \\
\hline 25 & Illerkirchberg $1(\mathrm{Ge})$ & N 48.31 E 10.046 & Burdigalian & $16.70-17.00$ & Andrias scheuchzeri & Sach and Heinzmann, 2001 \\
\hline 26 & Illerkirchberg hor. 3a (Ge) & N 48.31 E 10.04 & Burdigalian & $17.20-17.40$ & Andrias scheuchzeri & Böttcher, 1987 \\
\hline 27 & Reisensburg near Günzburg (Ge) & N 48.462 E 10.314 & Burdigalian & $17.30-17.60$ & Andrias sp. & Westphal, 1970 \\
\hline 28 & Ringingen-Frontal $2(\mathrm{Ge})$ & N 48.35 E 9.8167 & Burdigalian & $17.70-17.80$ & Andrias scheuchzeri & Sach and Heinzmann, 2001 \\
\hline 29 & Langenau $1(\mathrm{Ge})$ & N 48.5003 E 10.1219 & Burdigalian & $17.75-17.80$ & Andrias scheuchzeri & Böttcher, 1987 \\
\hline 30 & Hochberg near Jungnau (Ge) & N 48.1513 E 9.24447 & Burdigalian & $17.75-17.85$ & Andrias sp. & Westphal, 1970 \\
\hline 31 & Ringingen-Frontal $1(\mathrm{Ge})$ & N 48.35 E 9.8167 & Burdigalian & $17.75-17.85$ & Andrias scheuchzeri & Sach and Heinzmann, 2001 \\
\hline 32 & Břešt'any near Bilina (Cz) & N 50.5667 E 13.75 & Burdigalian & $18.00-19.00$ & Andrias scheuchzeri & Kvacek et al., 2004 \\
\hline 33 & Eggingen-Mittelhart (Ge) & N 48.3523 E 9.8598 & Burdigalian & $17.85-17.90$ & Andrias scheuchzeri & Sach and Heinzmann, 2001 \\
\hline 34 & Merkur North, Ahnikov (Cz) & N 50.45 E 13.4333 & Burdigalian & $20.00-20.00$ & Andrias sp. & Böhme, 2003; Kvacek et al., 2004 \\
\hline 35 & Rott near Hennef $(\mathrm{Ge})$ & N 50.7833 E 7.2833 & Chattian & $23.80-24.50$ & Andrias scheuchzeri & Westphal, 1958 \\
\hline 36 & Altyn Shokysu (Ka) & N 47.2724 E 61.025 & Chattian & $23.80-24.70$ & Zaissanurus beliajevae & this paper \\
\hline 37 & Oberleichtersbach (Ge) & N 50.35 E 10.05 & Chattian & $24.00-24.00$ & Andrias scheuchzeri & Böhme, 2008 \\
\hline 38 & Pancirny Sloy (Ka) & N 48.2158 E 84.3248 & Priabonian & $33.80-35.00$ & Zaissanurus beliajevae & Chkhikvadze, 1982 \\
\hline 39 & Maylibay (Ka) & N 47.4833 E 84.7183 & Rupelian & $31.00-33.80$ & Cryptobranchidae indet. & Chkhikvadze, 1984 \\
\hline 40 & Talagay, Tayzhuzgen section (Ka) & N 47.5984 E 84.00 & Rupelian & $31.00-33.80$ & Zaissanurus beliajevae & Chkhikvadze, 1982, 1984 \\
\hline 41 & Korablik (Ka) & N 48.00 E 84.50 & Priabonian & $33.80-34.60$ & Cryptobranchidae indet. & this paper \\
\hline 42 & Korsak B (Ka) & N 47.4733 E 85.51 & Priabonian & $35.00-37.00$ & Zaissanurus beliajevae & this paper \\
\hline 43 & Sopka obo (Ka) & N 48.2158 E 84.3248 & Priabonian & $35.00-37.00$ & Zaissanurus sp. & this paper \\
\hline 44 & Konur-Kura (Ka) & N 47.4401 E 84.4981 & Priabonian & $36.20-37.00$ & Zaissanurus beliajevae & Chkhikvadze, 1982 \\
\hline 45 & Kusto-Kyzylkain section (Ka) & N 47.6137 E 84.1009 & Priabonian & $35.00-37.00$ & Zaissanurus beliajevae & Chkhikvadze, 1982 \\
\hline 46 & Lager Biryukova (Ka) & N 48.2158 E 84.3248 & Priabonian & $35.00-37.00$ & Zaissanurus sp. & this paper \\
\hline 47 & Pod Chernim (Ka) & N 48.2158 E 84.3248 & Priabonian & $35.00-37.00$ & Zaissanurus sp. & this paper \\
\hline 48 & Yakor (Ka) & N 48.2158 E 84.3248 & Priabonian & $33.80-35.00$ & Zaissanurus sp. & this paper \\
\hline 49 & Belye Salamandry (Ka) & N 48.2158 E 84.3248 & Priabonian & $35.00-37.00$ & Zaissanurus sp. & this paper \\
\hline 50 & Tsagan-Khushu, Naran member, top (Mo) & N 43.455 E 100.37 & Thanetian & $55.80-56.00$ & Aviturus exsecratus & Gubin, 1991 \\
\hline 51 & Aguy-Dats-Bulak, Naran member, top (Mo) & N 43.455 E 100.50 & Thanetian & $55.80-56.00$ & Aviturus exsecratus & Gubin, 1991 \\
\hline 52 & Aguy-Dats-Bulak, Naran member, top (Mo) & N 43.455 E 100.50 & Thanetian & $55.80-56.00$ & Ulanurus fractus & Gubin, 1991 \\
\hline 53 & Aguy-Dats-Bulak, Naran member, layer 6 (Mo) & N 43.4667 E 100.445 & Thanetian & $56.02-56.04$ & Aviturus exsecratus & Gubin, 1991 \\
\hline
\end{tabular}

habitats, developed in basinal settings only during periods of increased basinal relief and/or very humid climates. Elevated ground-water levels and increased uplift and erosion will strengthen alluvial springs, whose discharge is regulated mainly by precipitation. This hypothesis can be tested in two well-studied and sampled Cenozoic basins: the European North Alpine Foreland Basin (NAFB) bounded by the Alpine orogene in the south, and the Central Asian Zaysan Basin in southeastern Kazakhstan, bounded by the Altai Mountains in the northeast and the Tian Shan, respectively Tarbagatai Mountains in the south (Fig. 3).

In the NAFB, Andrias fossils are known from 16 localities (Table 1, Fig. 4; Böttcher, 1987; Böhme and Ilg, 2003) within two narrow time periods: between 17.8 and $17.4 \mathrm{Ma}$ ( 8 localities from the Brackishwater Molasse and the earliest part of the Upper Freshwater Molasse - UFM), and between $\sim 13$ and $\sim 11.5 \mathrm{Ma}$ ( 8 localities from the Younger Series of the UFM, including the famous site of Oehningen, the type locality of
Andrias scheuchzeri). In hundreds of fossil localities analyzed, not a single cryptobranchid was found in the time-interval between the two periods (Böhme, 2010). The cryptobranchid-bearing intervals of the NAFB differ significantly in respect to temperature and vegetation (paratropical evergreen forests versus subtropical/warm temperate deciduous forests, Böhme et al., 2007), but show analogies in terms of basinal relief. Both times are characterized by erosion and hiatuses at the basin margin (Grimm, 1957), moderate alpine topography (Kuhlemann, 2007) and the incision of major valleys (e.g., Graupensand valley, Reichenbacher et al., 1998; Palaeo-Inn valley, Frisch et al., 1998) to which most cryptobranchid localities are bounded (Fig. 5).

From the Zaysan Basin, cryptobranchid salamanders are also known from two time periods only (Fig. 4). From the older period, ten localities derive from the Late Eocene (Late Aksyr and Kusto Formations) and two localities from the earliest Oligocene (Buran 


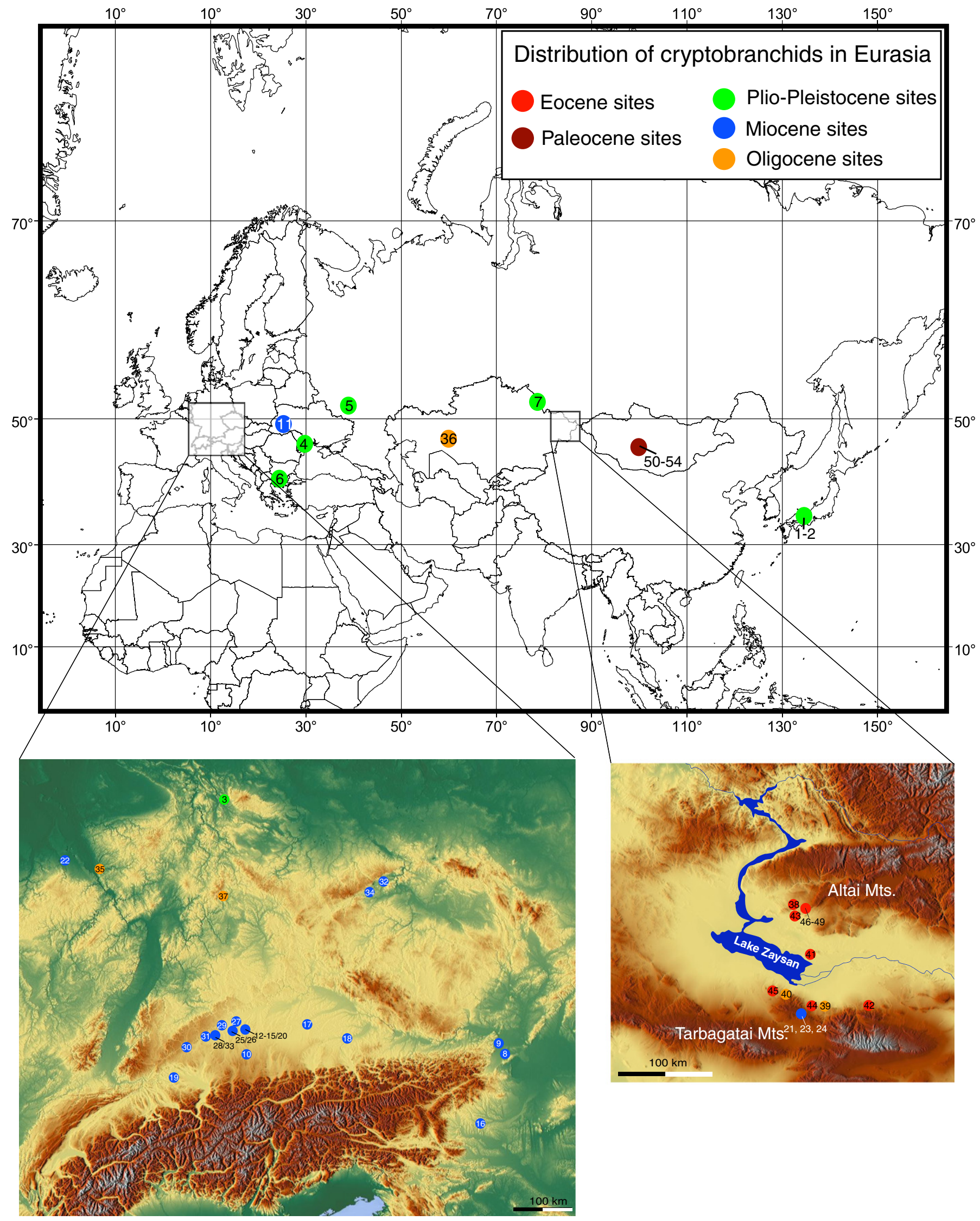

Fig. 3. Map of Eurasia showing the Cenozoic localities of giant salamanders. The dense record in Central Europe and the Zaysan Basin is shown in separate topographic maps. Numbers refer to localities in Table 1. 
Table 2

Mean annual precipitation (MAP) from climate stations within the distribution area of extant Eurasian and North American cryptobranchids.

\begin{tabular}{|c|c|c|c|}
\hline Climate station & Species & MAP & Reference \\
\hline Hiroshima & A. japonicus & 1.597 & Müller and Hennings, 2000 \\
\hline Osaka & A. japonicus & 1.360 & Müller and Hennings, 2000 \\
\hline Kyoto & A. japonicus & 1.585 & www.weather.com, 2010 \\
\hline Matsue & A. japonicus & 1.895 & $\begin{array}{l}\text { www.wunderground.com, } \\
2010\end{array}$ \\
\hline Tottori & A. japonicus & 1.950 & $\begin{array}{l}\text { www.wunderground.com, } \\
2010\end{array}$ \\
\hline Kobe & A. japonicus & 1.314 & $\begin{array}{l}\text { www.wunderground.com, } \\
2010\end{array}$ \\
\hline Yamaguchi & A. japonicus & 1.844 & $\begin{array}{l}\text { www.wunderground.com, } \\
2010\end{array}$ \\
\hline Chongqing & A. davidianus & 1.090 & Müller and Hennings, 2000 \\
\hline Guilin & A. davidianus & 1.967 & Müller and Hennings, 2000 \\
\hline Chengdu & A. davidianus & 1.146 & Müller and Hennings, 2000 \\
\hline Changsha & A. davidianus & 1.531 & Müller and Hennings, 2000 \\
\hline Nanchang & A. davidianus & 1.864 & Müller and Hennings, 2000 \\
\hline Wuhan & A. davidianus & 1.194 & Müller and Hennings, 2000 \\
\hline $\begin{array}{l}\text { Savannah } \\
\quad \text { River (GA, SC) }\end{array}$ & $\begin{array}{l}\text { C. } a \text {. } \\
\text { alleganiensis }\end{array}$ & 1.220 & www.wrcc.dri.edu, 2010 \\
\hline $\begin{array}{l}\text { Tennessee } \\
\quad \text { River (VA, TN, KY) }\end{array}$ & $\begin{array}{l}\text { C. } a \text {. } \\
\text { alleganiensis }\end{array}$ & $1.170-1.420$ & www.wrcc.dri.edu, 2010 \\
\hline $\begin{array}{l}\text { Ohio River } \\
\quad(\mathrm{PA}, \mathrm{OH}, \mathrm{IN})\end{array}$ & $\begin{array}{l}\text { C. } a \text {. } \\
\text { alleganiensis }\end{array}$ & $990-1.200$ & www.wrcc.dri.edu, 2010 \\
\hline Black River (MO) & C. a. bishopi & 1.140 & www.wrcc.dri.edu, 2010 \\
\hline White River (AR) & C. a. bishopi & 1.140 & www.wrcc.dri.edu, 2010 \\
\hline
\end{tabular}

Formation), suggesting that giant salamanders were present in the basin over a significant time span (Late Aksyr to Buran Formations) between 37 and $33 \mathrm{Ma}$. The second period (17 to $15 \mathrm{Ma}$ ) includes three localities crossing the Early to Middle Miocene boundary (Shamangora and Zaysan Formations). The regional tectonic evolution suggests that after a period of stability and regional peneplainization during the late Cretaceous to Paleocene a first period of tectonic deformation occurred in the Zaysan basin during the Late Eocene to Early Oligocene, including a regional uplift of the Altai Mountains (Buslov, 2004). A second period of tectonic movements along reactivated accretion-collision zones and faults is documented from the Middle Miocene (Buslov, 2004; DeGrave et al., 2007).

Therefore, the fossil distribution and tectonic data from both basins support the hypothesis that, besides elevated humidity increased basinal relief is necessary to provide spawning habitats for giant salamanders in lowland settings. Given these circumstances it is reasonable to assume that Central European giant salamanders lived permanently during the Neogene in mountain habitats of the Alpine orogene and colonized lowland basins only during periods of significantly elevated humidity and increased basinal relief (Fig. 6). We hypothesize the same for cryptobranchids of Central Asia where the Altai Mountains may act as a
$\mathrm{Ma}$

Western Eurasia Central Asia Eastern Eurasia

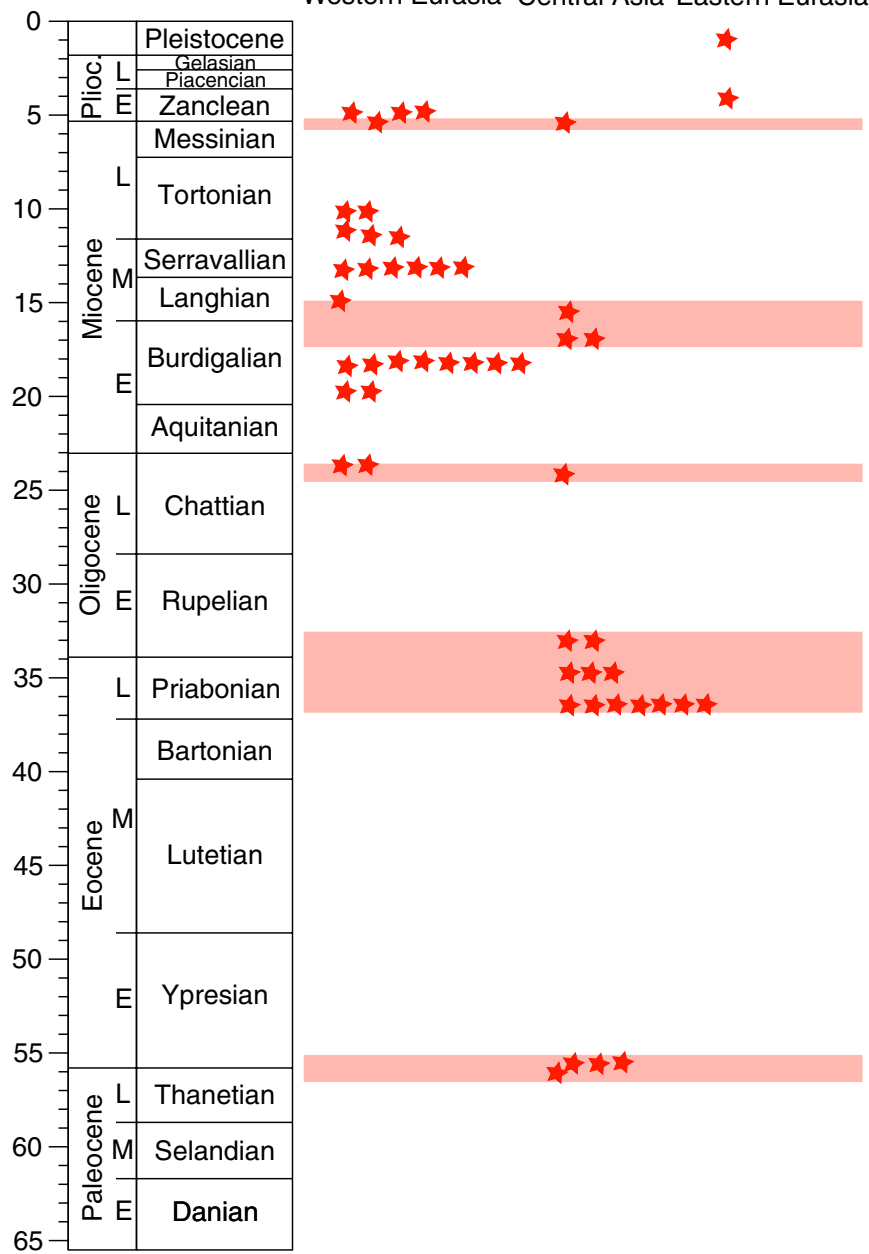

Fig. 4. Stratigraphic distribution of cryptobranchids in Eurasia during the Cenozoic. Western Eurasia covers Europe and the European part of Russia, Central Asia covers Kazakhstan, the Asian part of Russia and Mongolia, and East Asia document Japanese localities. The five periods when cryptobranchids are present in Central Asia are highlighted in grey.

refuge for giant salamander populations. In both cases, environmental stability will be maintained by habitat restriction to mountainous refuges during dry climates, and/or periods without suitable spawning habitats in the lowland basins. This model explains the high patchiness of giant salamander distribution in densely sampled basins and illustrates

Table 3

Mean annual precipitation (MAP) values of giant salamander localities from the Oligocene and Neogene of Europe and Asia.

\begin{tabular}{|c|c|c|c|c|c|c|}
\hline Locality & Country & Age (in Ma) & Stage & Species & MAP (in mm) & Reference \\
\hline Willershausen & Germany & $5.3-3.6$ & Zanclean & A. scheuchzeri & $897-1.151$ & Thiel et al., $2012^{*}$ \\
\hline Kuchurgan & Ukraine & $5.25-4.85$ & Early Zanclean & Andrias sp. & $1.425 \pm 273$ & Böhme, pers. comm. ${ }^{* *}$ \\
\hline Maramena & Greece & $5.5-5.25$ & Messinian/Zanclean & Andrias sp. & $994 \pm 257$ & Böhme, pers. comm. ${ }^{* *}$ \\
\hline Götzendorf & Austria & $9.94-9.78$ & Early Tortonian & A. scheuchzeri & $1.303 \pm 267$ & Böhme et al., $2008^{* *}$ \\
\hline Vösendorf & Austria & $10.45-10.25$ & Early Tortonian & A. scheuchzeri & $918 \pm 255$ & Böhme et al., 2008** \\
\hline Hammerschiede 1 & Germany & $11.28-11.08$ & Earliest Tortonian & Andrias sp. & $974 \pm 256$ & Böhme et al., 2008** \\
\hline Oehningen & Germany & 13.5-13.0 & Early Serravallian & A. scheuchzeri & $1.159-1.237$ & Mosbrugger et al., $2005^{*}$ \\
\hline Hambach $6 \mathrm{C}$ & Germany & $15.0-14.5$ & Late Langhian & A. scheuchzeri & $1.174 \pm 262$ & Böhme, pers. comm.** \\
\hline Reisensburg & Germany & $17.5-17.3$ & Late Burdigalian & A. scheuchzeri & $1.648 \pm 285$ & Böhme et al., 2011 ${ }^{* *}$ \\
\hline Langenau & Germany & $17.9-17.75$ & Late Burdigalian & A. scheuchzeri & $1.112 \pm 260$ & Böhme et al., 2011 ** \\
\hline Oberleichtersbach & Germany & $23.5-23.0$ & Latest Chattian & A. scheuchzeri & $1.131 \pm 261$ & Böhme, $2008^{* *}$ \\
\hline Rott & Germany & $23.5-23.0$ & Latest Chattian & A. scheuchzeri & $843-1.281$ & Utescher et al., $2000^{*}$ \\
\hline Altyn Shokysu & Kazakhstan & $23.8-24.7$ & Late Chattian & Z. beliajevae & $897-1.028$ & Bruch and Zhilin, 2007* \\
\hline
\end{tabular}

* Estimated by botanical proxy-method (Coexistence Approach, Mosbrugger and Utescher, 1997).

** Estimated by herpetofaunal proxy-method (Böhme et al., 2006). 


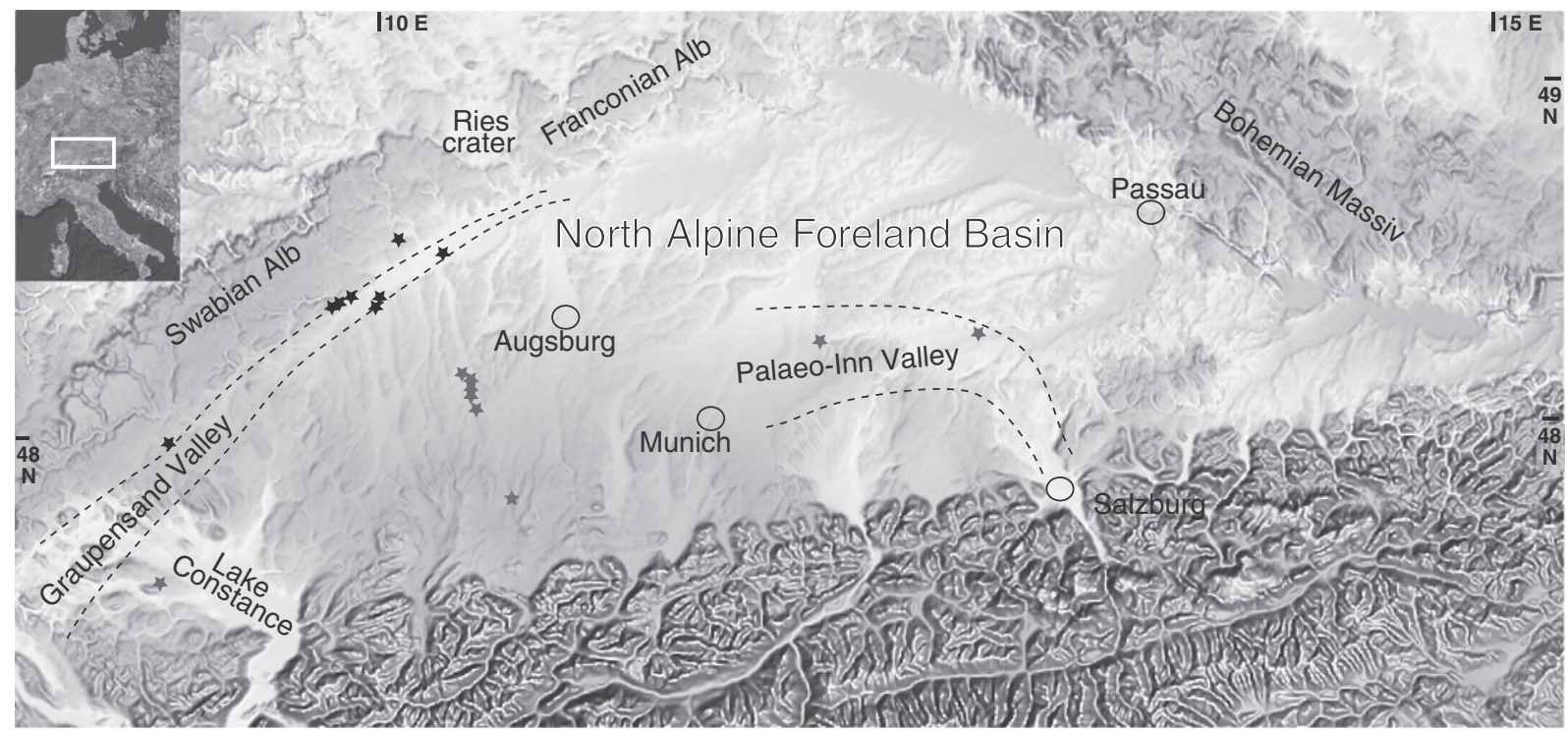

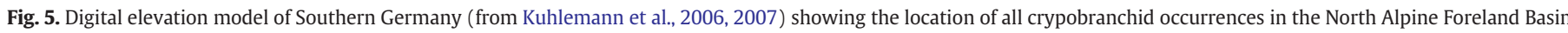

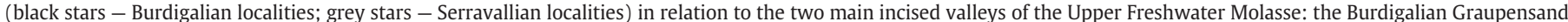
valley (according to Reichenbacher et al., 1998) and the Serravallian Palaeo-Inn valley (according to Frisch et al., 1998).

biogeographic patterns during 20 million years of cryptobranchid residence in Central Europe and Central Asia.

\section{Implications for Cenozoic palaeoclimatology of Central Asia}

Applying the relationship between giant salamander occurrences and humidity indicates that the five Central Asian cryptobranchid intervals (Fig. 4) are characterized by humid to very humid climates, with MAP above $900 \mathrm{~mm}$. Interestingly all but one interval represent global warm periods. Cryptobranchids from the oldest interval derive from the top of the Naran Member of the Naran Bulak Formation in south-central Mongolia (Tolstikova and Badamgarav, 1976: Fig. 4), which can be correlated to the late Gashatan Asian Land Mammal Age and the late Clarkforkian North American Land Mammal Age
(Meng and McKenna, 1998; Luterbacher et al., 2004; Secord et al., 2006), very near or contemporary with the Paleocene-Eocene Thermal Maximum. For both the Naran Member and the contemporary nearby Chinese Nomogen Formation humid environments have been already suggested (Tolstikova and Badamgarav, 1976; Van Itterbeeck et al., 2007). The second Central Asian cryptobranchid period covers not only the Late Eocene warming, but also the latest Eocene and the earliest Oligocene cooling periods (see Villa et al., 2008: Fig. 9). The third Central Asian cryptobranchid period is documented in latest Oligocene strata near the present-day Lake Aral (Aral Formation) and may correspond to the Late Oligocene warming, whereas the fourth cryptobranchid period is documented in the Zaysan basin again (Shamangora and Zaysan Formations). This period falls within the Miocene Climatic Optimum (Flower and Kennett, 1994; Böhme,
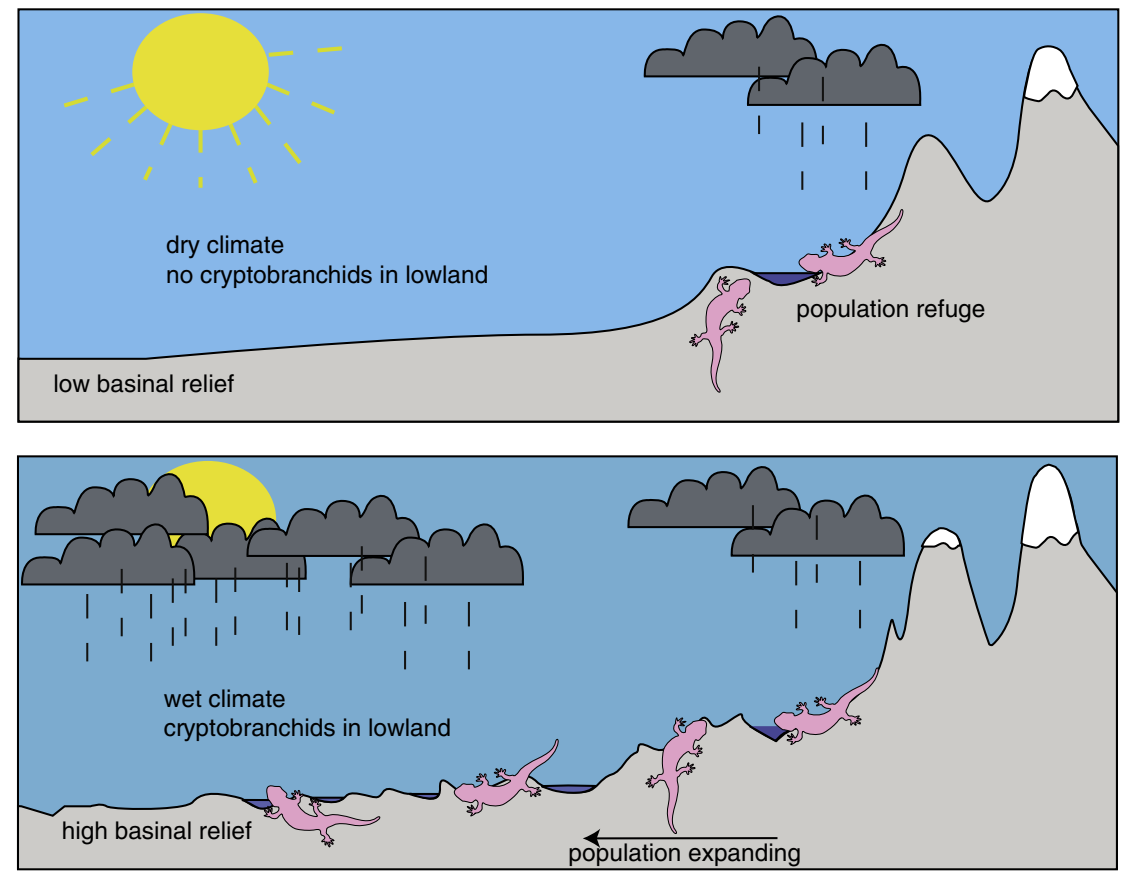

Fig. 6. Altitudinal distribution model of giant salamanders during dry climate and low basinal relief (above) and wet climate and high basinal relief (below). 
2003). The last Central Asian cryptobranchid populations are found at the Miocene/Pliocene transition, when giant salamanders are recorded from bio-magnetostratigraphically dated (5.6 to $5.3 \mathrm{Ma}$ ) sediments near Pavlodar (West Siberia).

\section{Conclusion}

Based on their environmental stability fossil cryptobranchids are excellent palaeoclimate proxies, indicating humid to very humid climates with MAP exceeding $900 \mathrm{~mm}$. Their fossil distribution in Eurasia is shown to be highly patchy and we hypothesize that they occur in basinal habitats only during humid periods of increased regional uplift. In Central Asia giant salamanders occur during five intervals, four of them are characterized as global warm periods (Paleocene-Eocene Thermal Maximum, Late Oligocene warming, Miocene Climate Optimum, Mio-Pliocene transition), suggesting a direct (positive) relationship between global temperature and Central Asian humidity evolution. The elevated and probably less seasonal humidity in Central Asia during global warm periods may be explained by a weak or absent Asian cold high pressure zone during winter months, allowing moist westerly winds (low-pressure systems) to penetrate far into the continent. The presence of cryptobranchids in the Zaysan Basin across the Eocene-Oligocene transition indicates that, unlike in Mongolia and northwest China where an intense aridification is recorded at this time (Böhme, 2007; Dupont-Nivet et al., 2007; Xiao et al., 2010), the Zaysan Basin exhibits a humid climate during this stepwise global cooling period. This may be explained by the contemporary uplift of the easterly bordering Altai Mountains and an increase in upslope precipitation.

\section{Acknowledgment}

We thank Dr. V. V. Chkhikvadze for making possible the study of Central Asian fossil cryptobranchids. We are grateful to editor Dr. Kershaw, as well as Dr. J. - C. Rage and anonymous reviewer for constructive comments. Financial support was provided by the Deutsche Forschungsgemeinschaft (grant number BO 1550/14).

\section{References}

Averianov, A., 2001. New record of proteid salamanders (Amphibia, Caudata) from the Pliocene of Ukraine and lower Pleistocene of Moldavia. Vestnik Zoologii 35, 43-46.

Böhme, M., 2003. Miocene climatic optimum: evidence from lower vertebrates of central Europe. Palaeogeography, Palaeoclimatology, Palaeoecology 195, 389-401.

Böhme, M., 2007. Oligocene-Miocene Vertebrates from the Valley of Lakes (Central Mongolia): Morphology, phylogenetic and stratigraphic implications. 3. Herpetofauna (Anura, Squamata) and palaeoclimatic implications: preliminary results. Annalen des Naturhistorischen Museums in Wien 108 A, 43-52.

Böhme, M., 2008. Ectothermic vertebrates (Teleostei, Allocaudata, Urodela, Anura, Testudines, Choristodera, Crocodylia, Squamata) from the Upper Oligocene of Oberleichtersbach (Northern Bavaria, Germany). Courier Forschungsinstitut Senckenberg 260, 161-183.

Böhme, M., 2010. Ectothermic vertebrates (Osteichthyes, Allocaudata, Urodela, Anura Crocodylia, Squamata) from the Miocene of Sandelzhausen (Germany, Bavaria): their implication for environmental reconstruction and palaeoclimate. Paläontologische Zeitschrift 84, 3-41.

Böhme, M., Ilg, A., 2003. fosFARbase. www.wahre-staerke.com2003(accessed April 2012).

Böhme, M., Ilg, A., Ossig, A., Küchenhoff, H., 2006. A new method to estimate paleoprecipitation using fossil amphibians and reptiles and the Middle and Late Miocene precipitation gradients in Europe. Geology 34, 425-428.

Böhme, M., Bruch, A., Selmeier, A., 2007. The reconstruction of the Early and Middle Miocene climate and vegetation in the North Alpine Foreland Basin as determined from the fossil wood flora. Palaeogeography, Palaeoclimatology, Palaeoecology 253, 91-114.

Böhme, M., Ilg, A., Winkelhofer, M., 2008. Late Miocene "washhouse" climate in Europe Earth Planetary Science Letters 275, 393-401.

Böhme, M., Winklhofer, M., Ilg, A., 2011. Miocene precipitation in Europe: temporal trends and spatial gradients. Palaeogeography, Palaeoclimatology, Palaeoecology 304, 212-218.
Böttcher, R., 1987. Neue Funde von Andrias scheuchzeri (Cryptobranchidae, Amphibia) aus der süddeutschen Molasse. Stuttgarter Beiträge zur Naturkunde B 131, 1-38.

Bruch, A.A., Zhilin, S.G., 2007. Early Miocene climate of Central Eurasia - evidence from Aquitanian floras of Kazakhstan. Palaeogeography, Palaeoclimatology, Palaeoecology $248,32-48$

Buslov, M.M., 2004. Cenozoic tectonics of central Asia: basement control. Himalayan Journal of Science 2, 104-105.

Chkhikvadze, V.M., 1982. On the finding of fossil Cryptobranchidae in the USSR and Mongolia. Vertebrata Hungarica 21, 63-67.

Chkhikvadze, V.M., 1984. Survey of the fossil urodelan and anuran amphibians from the USSR. Izvestia Akademii Nauk Gruzinska SSR, Seria Biologitcheskaya 10, 5-13 [in Russian].

DeGrave, J., Buslov, M.M., Van Den Haute, P., Dehandschutter, B., Delvaux, D., 2007. Meso-Cenozoic evolution of mountain range - intramontan basin system in the Southern Siberian Altai Mountains by apatite fission-track thermochronology. In: Lacombe, O., Roure, F., Lavé, J., Vergés, J. (Eds.), Thrust belts and foreland basins: from fold kinematics to hydrocarbon systems. Springer-Verlag Berlin Heidelberg, Berlin, Heidelberg, pp. 457-469.

Dupont-Nivet, G., Krijgsman, W., Langereis, C.G., Abels, H.A., Dai, S., Fang, X., 2007. Tibetan plateau aridification linked to global cooling at the Eocene-Oligocene transition. Nature 445, 635-638.

Flower, B., Kennett, J.P., 1994. The middle Miocene climatic transistion: east Antarctic ice sheet development, deep ocean circulation and global carbon cycling. Palaeogeography, Palaeoclimatology, Palaeoecology 108, 537-555.

Frisch, W., Kuhlemann, J., Dunkl, I., Brügel, A., 1998. Palinspastic reconstruction and topographic evolution of the Eastern Alps during the late Tertiary extrusion. Tectonphysics 297, 1-15.

Frost, D.R., Grant, T., Faivovich, J., Bain, R.H., Haas, A., Haddad, C.F.B., de Sá, R.O., Channing, A., Wilkinson, M., Donnellan, S.C., Raxworthy, C., Campbell, J.A., Blotto, B.L., Moler, P., Dreswes, R.C., Nussbaum, R.A., Lynch, J.D., Green, D.M., Wheeler, W.C., 2006. The amphibian tree of life. Bulletin of the American Museum of Natural History 297, 1-370.

Gao, K.-Q., Shubin, N.H., 2003. Earliest known crown-group Salamanders. Nature 422, 424-428.

Grimm, W.D., 1957. Stratigraphische und Sedimentpetrographische Untersuchungen in der Oberen Süßwassermolasse zwischen Inn und Rott (Niederbayern). Geologisches Jahrbuch, Beihefte 26, 97-199.

Gubin, Y.M., 1991. Paleocene salamanders from Southern Mongolia. Paleontologicheskij Zhurnal 1, 96-106 [in Russian].

Klembara, J., Böhme, M., Rummel, M., 2010. Revision of the anguine lizard Pseudopus laurillardi (Squamata, Anguidae) from the Miocene of Europe, with comments on paleoecology. Journal of Paleontology 84 (2), 159-196.

Kuhlemann, J., Dunkl, I., Brügel, A., Spiegel, C., Frisch, W., 2006. From source terrains of the Eastern Alps to the Molasse basin: detrital record of non-steady state exhumation. Tectonophysics 413, 301-316.

Kuhlemann, J., 2007. Paleogeographic and paleotopographic evolution of the Swiss and Eastern Alps since the Oligocene. Global and Planetary Change 58, 224-236.

Kvacek, Z., Böhme, M., Dvorak, Z., Konzalova, M., Mach, K., Prokop, J., Rajchl, M., 2004. Early Miocene freshwater and swamp ecosystems of the Most Basin (northern Bohemia) with particular reference to the Bilina Mine section. Journal of the Czech Geological Society 49 (1-2), 1-40.

Luterbacher, H.P., Ali, J.R., Brinkhuish, H., Gradstein, F.M., Hooker, J.J., Monechi, S., Ogg, J.G., Powell, J., Rohl, U., Sanfilippo, A., Schmitz, B., 2004. The Paleogene period. In: Gradstein, F., Ogg, J.G., Smith, A. (Eds.), A Geologic Time Scale. Cambridge University Press, Cambridge, pp. 384-408.

Masel, J., King, O.D., Maugham, H., 2007. The loss of adaptive plasticity during long periods of environmental stasis. The American Naturalist 169, 38-46.

Matsui, M., Kitabayashi, E., Takahashi, K., Sato, S., 2001. A fossil giant salamander of the genus Andrias from Kyushu, Southern Japan. Research Reports Lake Biwa Museum 18 72-28 [in Japanese].

Meng, J., McKenna, M.C., 1998. Faunal turnovers of Paleogene mammals from the Mongolian Plateau. Nature 394, 364-367.

Miklas, P.M., 2002. Die Amphibienfauna (Amphibia: Caudata, Anura) der obermiozänen Fundstelle Götzendorf an der Leitha (südliches Wiener Becken, Niederösterreich). Annalen des Naturhistorischen Museums in Wien 103A, 161-211.

Mosbrugger, V., Utescher, T., 1997. The coexistence approach - a method for quantitative reconstructions of Tertiary terrestrial palaeoclimate data using plant fossils. Palaeogeography, Palaeoclimatology, Palaeoecology 134, 61-86.

Mosbrugger, V., Uterscher, T., Dilcher, D.L., 2005. Cenozoic continental climate evolution of Central Europe. Proceedings of the National Academy of Science 102 (42), 14964-14969.

Müller, M.J., Hennings, D., 2000. The Global Climate Data Atlas on CD-Rom. Flensburg and Köln.

Reichenbacher, B., Böttcher, R., Bracher, H., Doppler, G., von Engelhardt, W., Gregor, H.J., Heissig, K., Heizmann, E.P.J., Hofmann, F., Kälin, D., Lemcke, K., Luterbacher, H., Martini, E., Pfeil, F., Reiff, W., Schreiner, A., Steininger, F.F., 1998. Graupensandrinne Ries-Impakt: Zur Stratigraphie der Grimmelfinger Schichten, Kirchberger Schichten 
und Oberen Süßwassermolasse. Zeitschrift Deutsche Geologische Gesellschaft 149, 127-161.

Sach, V.J., Heinzmann, P.J., 2001. Stratigraphie und Säugetierfaunen der Brackwassermolasse in der Umgebung von Ulm (Südwestdeutschland). Stuttgarter Beiträge zur Naturkunde. Serie B - Geologie und Paläontologie 310, 1-95.

Secord, R., Gingerich, P.D., Smith, M.E., Clyde, W.C., Wilf, P., Singer, B.S., 2006. Geochronology and mammalian biostratigraphy of Middle and Upper Paleocene continental strata, Bighorn Basin, Wyoming. American Journal of Science 306, 211-245.

Shikama, T., Hesegawa, Y., 1962. Discovery of the fossil giant salamander (Megalobatrachus) in Japan. Transactions of the Proceedings of the Paleontological Society of Japan, new series 45, 197-200.

Tempfer, M.A., 2004. Andrias scheuchzeri (Caudata: Cryptobranchidae) aus der obermiozänen (MN7/8) Fundstelle Mataschen/Steiermark. Joannea - Geologie und Paläontologie 5, 257-268.

Thenius, E., 1954. Über das Vorkommen von Riesensalamandern (Cryptobranchidae, Amphibia) im Unterpliozän (Pannon) des Wiener Beckens. Paläontologische Zeitschrift 28 (3/4), 172-177.

Thiel, C., Klotz, S., Uhl, D., 2012. Palaeoclimate estimates for selected leaf floras from the Late Pliocene (Reuverian) of Central Europe based on different palaeobotanical techniques. Turkish Journal of Earth Sciences 21, 263-287.

Tolstikova, N.V., Badamgarav, D., 1976. Freshwater gastropods from the lower Paleogene of Mongolia and southeast Kazakhstan. In: Kramarenko, N.N., Luvsandansan, B., Voronin, Yu.I., Barsbold, R., Rozhdestvensky, A.K., Trofimov, B.A., Reshetov, Yu, V. (Eds.), Palaeontology and Biostratigraphy of Mongolia (The Joint Soviet-Mongolian Paleontological Expedition, transaction vol. 3). Nauka, Moscow, pp. 145-150.
Utescher, T., Mosbrugger, V., Ashraf, A.R., 2000. Terrestrial climate evolution in Northwest Germany over the last 25 million years. Palaios 15, 430-449.

Van Itterbeeck, J., Missiaen, P., Folie, A., Markevich, V.S., Van Damme, D., Guo, D.-Y., Smith, T., 2007. Woodland in a fluvio-lacustrine environment on the dry Mongolian Plateau during the late Paleocene: evidence from the mammal bearing Subeng section (Inner Mongolia, P.R. China). Palaeogeography, Palaeoclimatology, Palaeoecology 243, 55-78.

Villa, G., Fioroni, C., Pea, L., Bohaty, S., Persico, D., 2008. Middle Eocene-late Oligocene climate variability: calcareous nannofossil response at Kerguelen Plateau, Site 748. Marine Micropaleontology 69, 173-192.

Wake, D.B., Roth, G., Wake, M.H., 1982. On the problem of stasis in organismal evolution. Journal of theoretical Biology 101, 211-224.

Westphal, F., 1958. Die Tertiären und rezenten Eurasiatischen Riesensalamander Palaeontolographica Abt. A 110, 20-92.

Westphal, F., 1967. Erster Nachweis des Riesensalamanders (Andrias, Urodela, Amphibia) im europäischen Jungpliozän. Neues Jahrbuch für Geologie und Paläontologie - Monatshefte 67-73.

Westphal, F., 1970. Neue Riesensalamander-Funde (Andrias, Amphibia) aus der Oberen Süßwassermolasse von Wartenberg in Bayern. Mitteilungen der Bayerischen Staatssammlung für Paläontologie und historische Geologie 10, 253-260.

www.weather.com National and local weather forecast, hurricane, radar and Report (accessed April 2010).

www.wrcc.dri.edu Western Regional Climate Center (accessed October 2010). www.wunderground.com Weather underground. (accessed April 2010).

Xiao, G.Q., Abels, H.A., Yao, Z.Q., Dupont-Nivet, G., Hilgen, F.J., 2010. Asian aridification linked to the first step of the Eocene-Oligocene climate Transition (EOT) in obliquitydominated terrestrial records (Xining Basin, China). Climate of the Past 6, 501-513. 